\title{
Fraud, Illegality and Corruption in the Export of Used Goods from the United States
}

\author{
Frances L. Edwards, J.D \\ Associate Professor \\ Legal Studies \\ School of Accountancy \\ College of Business \\ Clemson University
}

There is a very large global market for used goods exported from the United States. On the top of the list of demand of used items are used vehicles; used car parts; used telephone and telecommunications equipment and parts; and most notably in the area of fraudulent activity, used clothing. This article will discuss the area of exporting used clothing from the U.S. to Europe. To highlight the problem that exists to especially small business exporters, the article will discuss a South Carolina case, Rodcelt, Inc. v. Kinsaka in which the defendant was accused of fraud and misrepresentation in the sale of a 40-foot container of worthless used clothing, which was packaged and prepared for export by the buyer, Rodcelt.Used clothing is usually presented in bales of clothing articles that are transported in 40foot containers by ocean freight. Large orders for export of this product involve thousands of dollars per transaction. The United States, the largest exporter of used clothing generates 1.4 million tons of this product, with exports of 800,000 tons annually. ${ }^{1}$ (See Table 1.$)$

Table 1

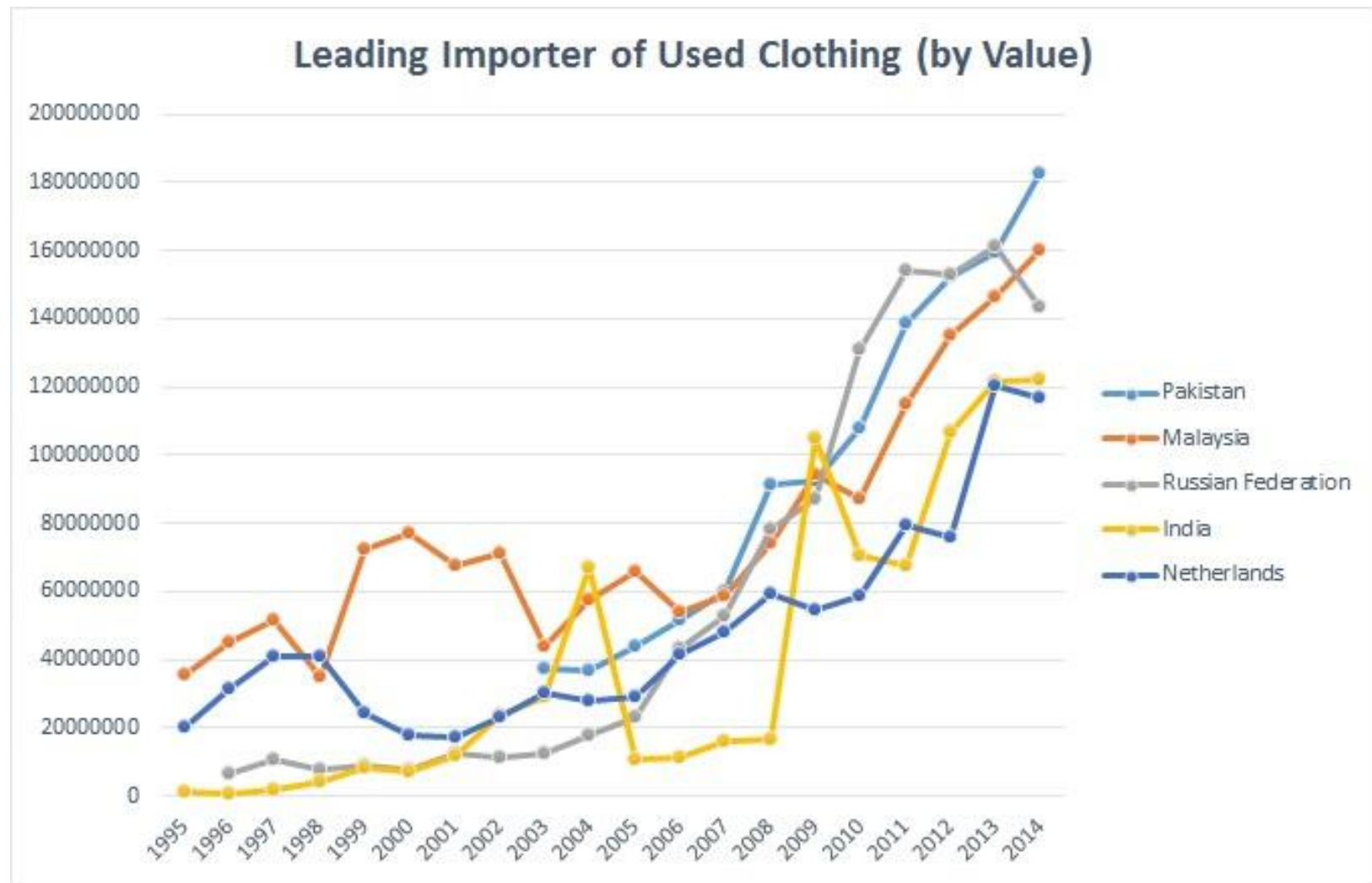

Shenglufashion Wordpress, Global Trade of Used Clothing (Sept. 30, 2015), https://shenglufashion.wordpress.com/2015/09/30/global-trade-of-used-clothing/.

\footnotetext{
${ }^{1}$ Shenglufashion Wordpress, Global Trade of Used Clothing (Updated October, 2015), https://shenglufashion.wordpress.com/2015/09/30/global-trade-of-used-clothing/. 
The OEC (The Observatory of Economic Complexity) indicates that used clothing is the 545th most traded product and the 861 st most complex product according to the Product Complexity Index (PCI). ${ }^{2}$ According to the OEC the top exporters of used clothing are the United States at $\$ 785 \mathrm{M}$, followed by Germany $(\$ 384 \mathrm{M})$ and the United Kingdom $(\$ 347 \mathrm{M})$. The top Asian exporters are Korea $(\$ 260 \mathrm{M})$ and China $(\$ 247 \mathrm{M}){ }^{3}$.

Because these items come from the U.S., it is presumed by international buyers of these goods that they will be of high quality, with the almost mythical belief that the U.S. government is monitoring not only those who export the goods, but also the quality of the goods themselves. In many cases, all of these presumptions are far from the truth. Exported equipment and machinery are of poor quality, some of which do not function well or do not even work at all. ${ }^{4}$ Used clothing is a special problem, as much of the clothing is generally unclean, filled with bacteria, unusable, and in too many cases, simply trash. (For instance, the average amount of used clothing that must be destroyed from any one 40foot container is between $33-50 \%$ of the entire amount of goods purchased. $)^{5}$

The fraud that is perpetrated comes in different categories. One type is that a U.S. exporter in good faith buys items from a used clothing warehouse and sells to an overseas buyer. When the items arrive, the buyer is shocked to find that the items are not of good quality or unusable. In such a case, both the distributer (who has purchased the used clothing from a U.S. warehouse) and the foreign buyer are defrauded. The result is that, depending on the financial arrangements between the buyer and the seller, one or both will lose money on the transaction. Not only is the loss for the amount actually paid for the goods, but also import taxes on the items that cannot be recouped for the international buyers since the items cannot be resold in a secondary market. ${ }^{6}$ In an order for a container sent to Krystof Sionkowski Company by Rodcelt, Inc., a Rodcelt agent paid 8,400 Polish Zloty to customs agents. At that time the average gross income in Poland per worker was approximately 3781.14 Polish Zloty. ${ }^{7}$ The relationship between the seller and the buyer often deteriorates, which means a loss of future revenue to both parties. The KrystofSionkowski Company, Rodcelt, Inc.'s foreign buyer of used clothing, finally went bankrupt from his losses. ${ }^{8}$ Additionally others lost money as loans to Sionkowski that was never repaid. ${ }^{9}$ In addition, since many European countries are "green", there are costs of literally hauling away the "trash" that the buyer has received and who must nowpay for proper recycling, which can be quite expensive. Under a new system in Poland, for instance, households will pay a month tax. This tax, calculated based on each municipality, which can choose its taxing criteria such as a home's square footage or a flat rate taxing. ${ }^{10}$ The hope is that once the tax is paid the usual process of dumping garbage cans in the woods will be eliminated. ${ }^{11}$ However, Poles are coming up with creative ways to cheat this taxing system. One way is for apartment owners to claim few residents on their tax filing forms. ${ }^{12}$ In Warsaw, for instance, based on the declarations submitted, it is estimated that only 600,000 people out of a population of 2,000,000 million have made proper declarations for this taxing purpose. ${ }^{13}$

${ }^{2}$ OEC, Used Clothing (1995-2015), http://atlas.media.mit.edu/en/profile/hs92/6309/.

${ }^{3} \mathrm{Id}$.

${ }^{4}$ ROGER E. MEINERS, AL H. RINGLEB \&FRANCES L. EDWARDS, THE LEGAL ENVIRONMNET OF BUSINESS $\left(13^{\text {th }}\right.$ ed.2015). Government and industrial fraud are not fundamentally different. Both government and corporations find themselves defrauded by unscrupulous sellers.

${ }^{5}$ According to one experienced importer of used clothing. Telephone interview with Kristof Sionkowski, Company, Tomaszow-Maz, Poland (July 19, 2010).

${ }^{6}$ Confidential accounting information, J.M. Dorociak, Agent of Rodcelt, Inc., September 17, 2014.

${ }^{7}$ See Table 3.

${ }^{8}$ Krystof Sionkowski declared bankruptcy in September 2015, id.

${ }^{9}$ Losses included the following persons related to Krystof Sionkowski: Hanna Sionkowska, Krystof Sionkowski's wife from her personal earnings; Magda Sionkawska of Lodz, Poland, and daughter of Krystof Sionkowski; Bartek Sionkowski, son of Krystof Sionkowski and now working and residing in England in order to recoup his losses to his father; Krystof Sionkowski's sister and her husband who closed their rather lucrative vegetable market in Opoczno, Poland to start a used clothing business with Sionkowski (and later the couple went bankrupt in September 2014 as well) and Rodcelt, Inc. who loaned KrystofSionkowski \$6000, from October 2004 to January 2005 (taken from Rodcelt accounting records and promissory notes dated October 31, 2004 and January11, 2005. In order to continue to receive loans from Rodcelt, Inc. KrystofSionkowski made payments on interest owed to Rodcelt, leaving Rodcelt with \$6465.55 in unpaid loans and interest.

10 Dawn, Poland Dumps Old Garbage System For Greener Setup. p. 2 (AFP Updated May 29, 2013),https://www.dawn.com/news/1014695/poland-dumps-old-garbage-system-for-greener-setup.

${ }^{11}$ Id.

${ }^{12} \mathrm{Id}$.

${ }^{13}$ Id. Zbigniew Gawron, head of an association of Warsaw housing cooperatives, was quoted as saying by the Gazeta Wyborcza Daily. 
(For a comparison of European Gate Fees and Landfill Taxes by country, see Table 2.)

Table 2Typical charge (gate fee and landfill tax) for legal landfilling of non-hazardous municipal waste in EU

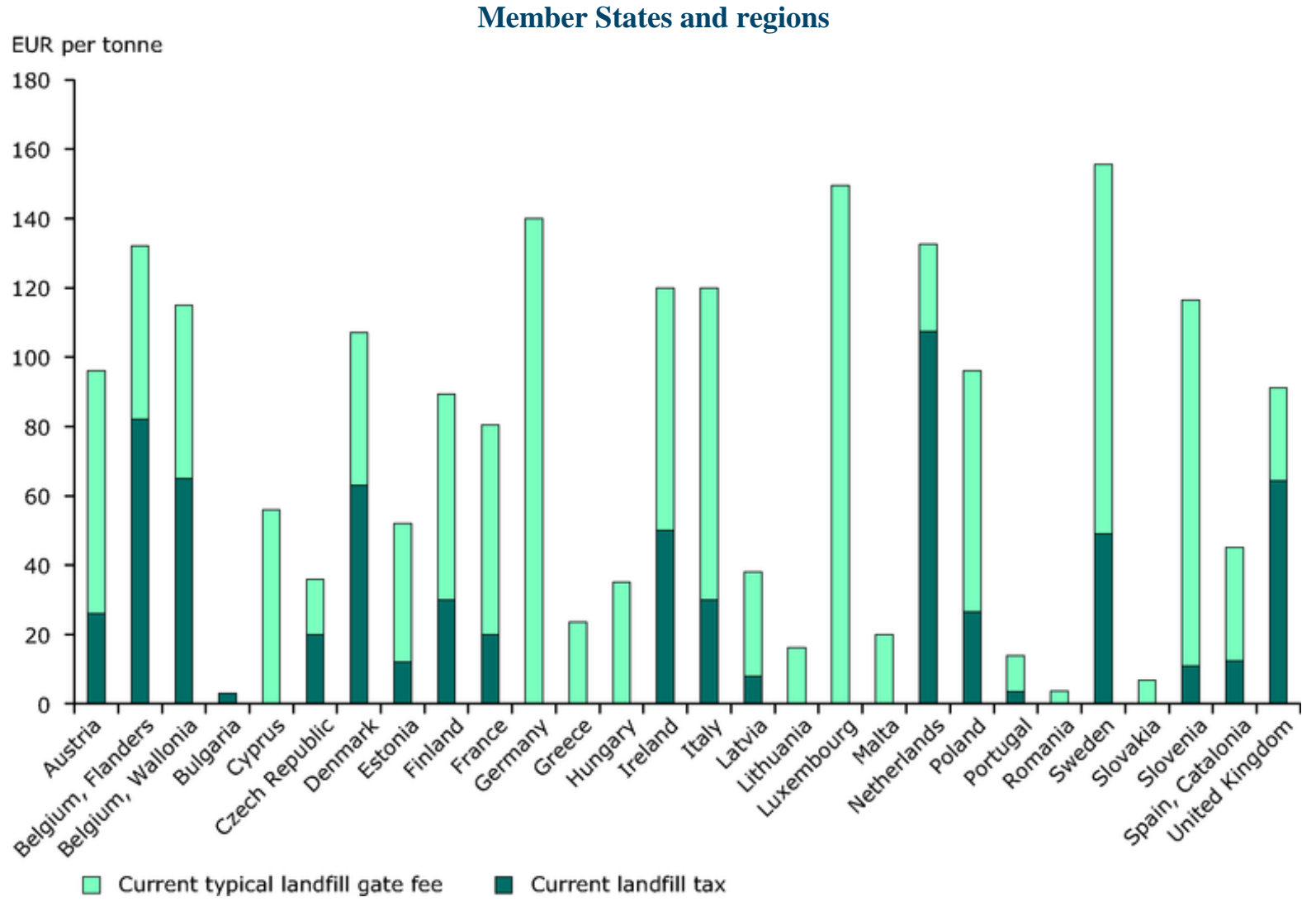

Figure Created 20 Feb 2013. Published 19 Mar 2013. Last modified 19 Mar 2013.

https://www.eea.europa.eu/data-and-maps/figures/typical-charge-gate-fee-and

In order to use waste more productively, the Confederation of European Waste-to-Energy Plants has estimated costs by country for the purpose of pricing of waste to energy-creating plants in order to use waste more productively. ${ }^{14}$ It may be that in other parts of the world,such as Central America, South America, Africa and the Middle East, the items are literally "dumped", which adds to pollution and clean-up costs that may later be borne by the governments or simply creates pollution to waterways.A second type of fraud comes in the way of illegal items being smuggled among the goods that are shipped to the buyer. In this case, both the buyer and the seller are aware of the illegality of the transaction and will share in the profits from the scheme. (An example is a number of containers that had U.S. cigarettes hidden among the bales of used clothing sent to the UK and Ireland. With no amounts paid on the neither cigarettes nor payment of taxes on these tobacco products sold in foreign markets, the revenues from the name-brand items and the profit from unpaid taxes made the illegal transaction highly lucrative.

\footnotetext{
${ }^{14}$ CEWEP is an association of owners and operators of Waste-to Energy Plants. They represent approximately 400 Waste-to Energy plants located in 22 countries. It is estimated that this makes up over $80 \%$ of the Waste-to-Energy capacity in Europe. "Waste-to-Energy Plants (waste incineration with energy recovery) thermally treat residual household and similar waste that cannot otherwise be reused or recycled in an environmentally or economically beneficial way, and generate energy from it. Recycling and Waste-to-Energy are complementary waste treatment methods. Together they are instrumental in order to divert waste from landfills and reduce Greenhouse gas emissions. This avoids the creation of methane in landfills, a potent greenhouse gas (25 times more significant in mass than $\mathrm{CO} 2$ ). Waste-to-Energy Plants also help to ensure quality recycling by treating the waste that is not good enough for recycling.Membership of CEWEP underlines a Waste-to-Energy Plant's commitment to ensuring high environmental standards, achieving low emissions by operating Best Available Techniques and maintaining state of the art energy production from not otherwise reusable or recyclable materials. The plants represented by CEWEP are operated both by municipalities and private companies. Members are mostly national associations, but also individual plants." http://www.cewep.eu/about/cewep/index.html. For example in Poland the VAT is $23 \% 26.6 € / t$, with typical charges: $28.13-92.94 € / t$ (but mostly $48.92 € / \mathrm{t}$ ) since 1.1 .2013 on combustible waste collected separately. From CEWEP Table. http://cewep.eu/media/cewep.eu/org/med_557/1200_2014-02-06_cewep_-_landfill_inctaxesbans.pdf.
} 
A third and flourishing illegal activity, especially in Central and South America, are items shipped to "charitable organizations". The seller sends the items to the buyer who receives the goods for pennies and then pawns the merchandise off as "new" or "barely used", sustaining large, tax-free profits.Againusually both the buyer and seller are involved in the scheme. With pennies paid for the product, the buyer and seller agree on the split of profit either before or after the sale of the items. A typical example of this comes from Columbia, South America. "According to prosecutors, the network established five apparently legitimate businesses, among them two of Colombia's biggest clothes exporters, which were used to exploit tax and customs loopholes in a "technical contraband" operation -smuggling where the products are moved in through legal channels but with fraudulent documentation." ${ }^{15} \mathrm{~A}$ fourth offshoot of many of these types of transactions involves a number of adjacent corruption schemes necessary to carry out the fraud and/or illegality. Often the most basic need of any illegal or fraudulent transaction is the bribing of customs officials at the receiving port and other officials involved in the transaction. In some countries, such as the former USSR countries, there is often a "Mafia" transaction. In such a case, money will first have to be paid to the local or sometimes highly organized "Mafia" who set up a system (either through or with the knowledge ofthe receiving countries' customs officials). ${ }^{16}$ After the bribe is made to the Mafia "customs control", the goods are then forwarded to the country's official customs for control. At this point a second bribe is necessary. This is easily done in countries in Eastern Europe, Central and South America, Africa and the Middle East.Once called bribery and now just recognized as a necessity for doing business. "Bribery is certainly not new to Russia, but, according to several recent surveys and interviews with dozens of ordinary Russians, it has surged in scale and scope in recent years under the presidency of Vladimir Putin. Now it is touching about every aspect of life." The same has been true for importers into Russia. $^{17}$

An example of corruption was, and perhaps still is, in Poland prior to it becoming a part of the European Union. The average bribe for a 40 -foot container was about US $\$ 150$ per container. Any one agent will clear 5-7 containers per day, which would equal approximately US \$750-1050 in payments per day. Thus in one month, any one customs agent could receive US \$15,000-21,000 per month in payments above and beyond his salary per month. This would equal up to $\$ 180,000-252,000$ per year. Compared to the average income of $\$ 850$ for a Polish worker at that time, these customs officials make simply a fortune. ${ }^{18}$ (See Table 3) "However, the government does not prosecute these offences effectively, and officials engage in corruption with impunity. Sectors most prone to corruption are public services and public procurement. Despite facilitation payments and gifts being criminalised, these practices are widespread." ${ }^{19}$ Lawsuits, such as RODCELT, INC. vs. Peto Kinsaka, d/b/a/ KIN'S IMPORT-EXPORT COMPANY, ${ }^{20}$ have been filed by many, but sometimes with no avail. ${ }^{21}$ The defendants ofthese lawsuits often change their companies' names and/or locations and often will create fraudulent conveyances to friends, family members and other cohorts in order to hide their assets from plaintiffs. ${ }^{22}$

The Rodcelt, Inc. lawsuit alleged, among other things, fraud against the company. Rodcelt has been doing business in the State of South Carolina since 2003 and is a legitimate company that does domestic and overseas business. ${ }^{23}$ In order

15 James Bargent, Textiles and Organized Crime: How Everyday Products Turn Criminal Profits, INSIGHT CRIME: INVESTIGATION AND ANALYSIS OF ORGANIZED CRIME (April 30 2015), http://www.insightcrime.org/newsanalysis/textiles-and-organized-crime-how-everyday-products-turn-criminal-profits.

16 Steven Lee Myers, "In Russia, Bribery is the Cost of Business N.Y. TIMES (August 8, 2005),http://www.nytimes.com/2005/08/10/world/europe/in-russia-bribery-is-the-cost-of-business.html?_r=0;

Conversation with Rodcelt, Inc.'s exporting agent, J.M. Dorociak, Anderson, SC (February 17, 2011).

${ }^{17} \mathrm{Id}$.

${ }^{18}$ Trading Economics, Poland Average Gross Wage (1997-2017), http://www.tradingeconomics.com/poland/wages. See also Check in Price, Average and Minimum Salary in Warsaw, Poland Posted in Europe, Work Abroad Guide (March 13, 2017), http://checkinprice.com/average-and-minimum-salary-in-warsaw-poland/. See also Trading Economics, Poland Corruption Rank (1996-2017) https://tradingeconomics.com/poland/corruption-rank.

${ }^{19}$ GAN Business Anti-Corruption Portal, Poland Corruption Report: Snapshot, (December, 2015), http://www.business-anticorruption.com/country-profiles/poland.

${ }^{20}$ Rodcelt, Inc. vs. Peto Kinsaka, et al., Case No. 2010CP3901146, (Pickens Cty., S.C. 13 ${ }^{\text {th }}$ Judicial Circuit, Dec. 14, 2010.

${ }^{21}$ In the Rodcelt case, id, one of the defendants, Edward Fode, was supposedly to be located in Houston, Texas, and the plaintiffs had to use substituted service in order for the South Carolina court to have jurisdiction over him. See also Meiners, supra at 32-34 for difficulties in service of process over some defendants, especially those outside the court's jurisdiction.

${ }^{22}$ See general discussion. Douglas G. Baird and Thomas H. Jackson, Fraudulent Conveyence Law and Its Proper Domain, 830 VAND. LAW REV. (1985).

${ }^{23}$ Supra, 16. See also Rodcelt, Inc. corporation good standing at South Carolina Business Entities Online: File, Search, and Retrieve Documents Electronically (Effective July 18, 2003), 
to do business, Mr. Kinsaka has in the past met clients either in South Carolina or has met them at his warehouse in Charlotte, North Carolina. In the Rodcelt lawsuit, as well as other complaints to police department and municipal judges, Kinsaka promises to sell and ship products, such as used clothing and other items. He requires an up-front wire transfer. He first shows the client the good quality of the products and later has the client look at the nice and very professional packaging of the products. Hethen sends the products with unusable items inside, according to the lawsuit and other allegations to authorities. There have been complaints about him on the North Carolina Better Business Bureau, which now indicates that he is no longer registered under his previous name. ${ }^{24}$

PetoKinsaka and Kin's Import/Export did not appear in court and defaulted in the Rodcelt, Inc. lawsuit. Damages granted by the South Carolina Court were approximately $\$ 32,000$ in actual damages plus approximately $\$ 64,000$ in punitive damages. ${ }^{25}$ His alleged partner in this lawsuit (known as Edward Fode of Fobrose, LLC) was reached by phone in Houston, Texas, but has not been in any of his known locations for service of process. ${ }^{26}$ Furthermore, when the Rodcelt agents have contacted him through his cell phone to meet with them, he refused to do so. ${ }^{27}$ There are numerous complaints of these kind of fraudulent activities sent to the Better Business Bureau every year. However, the BBB only assists in negotiating concerns, and then tallies the number of complaints and resolutions against a given company.

\section{Conclusion}

Companies such as Rodcelt, Inc. are affected by the fraud and corruption associated with the export of used clothing from the U.S. to foreign companies. In the case of Peto Kinsaka, an agent of Rodcelt, Inc. asked the prosecutor's office in Charlotte, North Carolina to bring criminal allegations against Kinsaka. ${ }^{28}$ In the discussion, the representative of the prosecutor's office indicated to the president of Rodcelt, that there were many cases to be handled by the office, and this smaller sum deed not warrant the attention that larger losses would. When asked if more than $\$ 95,000$ to a smaller company is significant and would merit consideration since this loss would be sizeable to Rodcelt, the prosecutor's representative indicated again that this was a small amount in comparison to other cases where the loss has been greater losses. Unfortunately, it appears that the constitutional privilege of "equal protection under the law" is guided in some cases by the monetary losses deemed worthy of such protection. ${ }^{29}$

https://businessfilings.sc.gov/BusinessFiling/Entity/Profile/d9c86ab5-0991-4cc0-b3ae-4f6086b9b502.

24،BBB File Opened: 5/20/2005.Out of Business. According to information in BBB files, this company is no longer in business. If you have an unresolved dispute with this company you may wish to seek legal advice. Principal: Mr. Peto Clement Kinsaka",https://www.bbb.org/charlotte/business-reviews/business-opportunity-companies/kins-import-export-incharlotte-nc-120033. One allegation states, "The Better Business Bureau that rates business in North and South Carolina has graded his business "F," because Mr. Kinsaka couldn't respond to complaints and the business could not be verified.. . . According to the police, six years ago, Mr. Kinsaka was arrested on fraud charges. In recent times, they've received more than a dozen complaints about his on-going scams. The police said the victims went into contract with his business. . .GHANAWEB, Fraud alert email for Ghanaians (February 9,

2010),http://www.ghanaweb.com/GhanaHomePage/NewsArchive/Fraud-alert-email-for-Ghanaians-176329.

${ }^{25}$ Supra, note 16.

${ }^{26}$ Conversation with Edward Fode by Rodcelt Agent, J.M. Dorociak. April 21, 2009.

${ }^{27}$ Id, April 22, 2009.

${ }^{28}$ President, Rodcelt, Inc. Conversation, Mecklenburg County Prosecutor's Office. March 22, 2011.

${ }^{29}$ U.S.CONST.amend.XIV, $§ 1$."nor deny to any person within its jurisdiction the equal protection of the laws." 
Table 3

POLAND AVERAGE GROSS WAGE

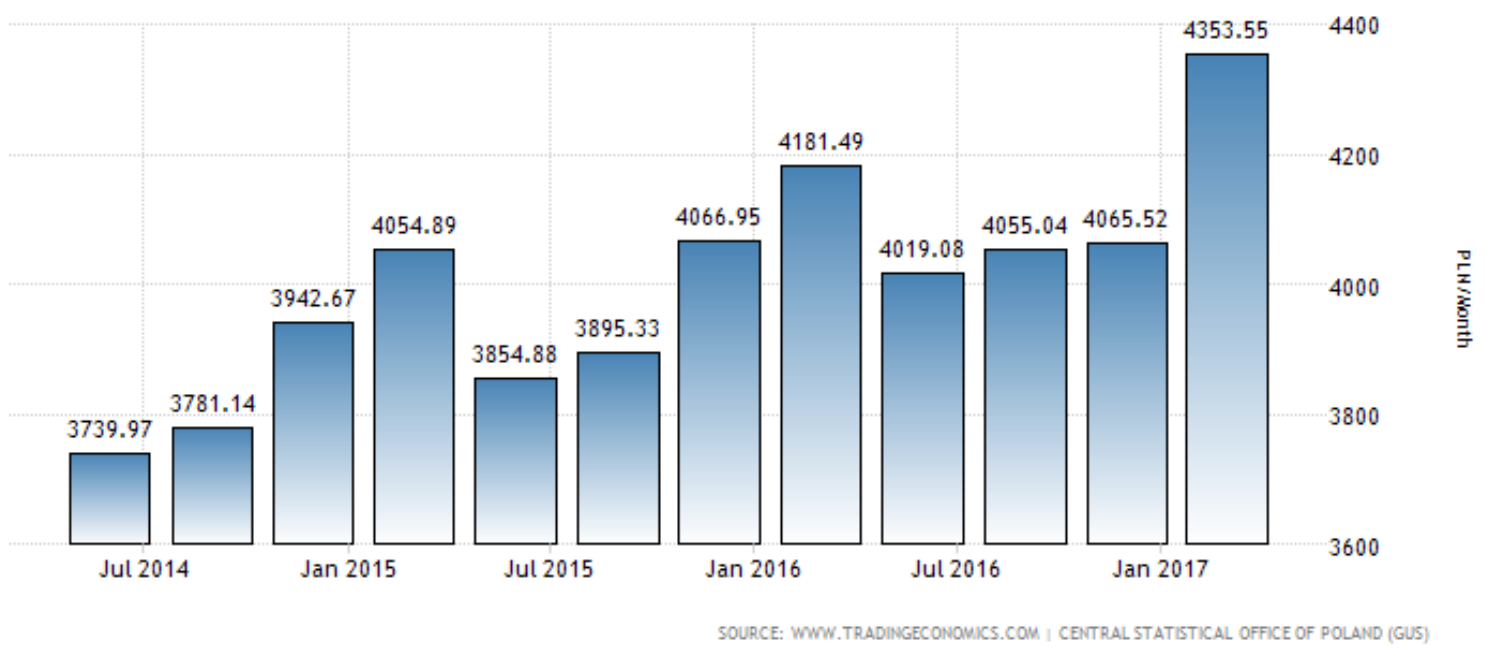

Trading Economics, Poland Average Gross Wage (1997-2017), http://www.tradingeconomics.com/poland/wages. 